\title{
A Study on the Influence of the Host Country's Legal System on the Performance of Chinese Enterprises' Foreign Direct Investment Empirical analysis based on micro data of Chinese listed companies
}

\author{
$\mathrm{Xia} \mathrm{Qu}^{1, \mathrm{a}}, \operatorname{Ran} \mathrm{Li}^{* 2, \mathrm{~b}}$ \\ ${ }^{1}$ School of Economics and Management, Beijing Jiaotong University, Beijing, China \\ ${ }^{2}$ School of Economics and Management, Beijing Jiaotong University, Beijing, China
}

\begin{abstract}
In recent years, while the direct investment of Chinese enterprises has made rapid progress in foreign direct investment, it has also shown a trend of "blindness" and "irrationality", which has brought huge overseas investment risks. The reason is largely due to foreign investment enterprises ignore the host country's legal system. This paper uses 82 foreign direct investment data of Chinese listed companies in 30 countries (regions) from 2010 to 2019 as a research sample to analyze the impact of the host country's legal system on the performance of Chinese companies' foreign direct investment. The results show that the performance of Chinese enterprises' investment in the country has gradually improved with the improvement of the economic development level of the host country, the soundness of the legal system of the host country has been continuously improved. The restraining effect of the soundness of the host country's legal system on investment performance is more obvious in state-owned enterprises and investments involving sensitive industries or key areas. In addition, the performance of investment enterprises will gradually improve with the increase in the density of labor unions and the international investment experience of enterprises.
\end{abstract}

\section{Introduction}

In recent years, while the direct investment of Chinese enterprises has been advancing rapidly, it has also shown a trend of "blindness" and "irrationality", which has brought huge overseas investment risks. We calculated China's foreign investment performance index based on data from the United Nations Conference on Trade and Development (UNCTAD) and the World Bank website, and found that the average of this index from 2006 to 2018 was only 0.59 , which was lower than the world average. The Ministry of Commerce report also pointed out that only $13 \%$ of overseas investment projects of Chinese enterprises have achieved profitability, and $63 \%$ are in the situation of non-profit or loss-making. The low performance rate of Chinese companies' overseas M\&A has been criticized, and it has become a problem that plagues Chinese companies' foreign investment. A large part of the reason is that China's corporate legal awareness is weak, and the legal risks and legal systems of foreign investment are ignored. In previous cases of investment failures, on the one hand, many Chinese companies' foreign investment was directly blocked by the host country's foreign investment legal system, and they were unable to successfully enter the host country for investment due to the host country's foreign capital access or security review system restrictions. On the other hand, even if they successfully entered the host country's longterm operation stage, many companies failed to follow the relevant domestic legal systems of the host country, including labor rights legal system, environmental protection legal system, intellectual property protection system, data protection system, export control system, anti-corruption legal system, etc., which triggered the host country's laws risks, resulting in failure to obtain expected investment performance and even investment losses are not uncommon.

Over the years, many scholars have conducted in-depth research on the overall evaluation of the performance of enterprises' foreign direct investment and its influencing factors, and the research conclusions also have their own focus. In terms of performance evaluation, some scholars conducted a study on the measurement dimensions of the performance of Chinese companies' foreign direct investment and their performance evaluation system[1-4]. They found that only when the company's overseas assets stock reaches the corresponding critical point or critical ratio, companies can obtain positive performance improvement from foreign investment. However, the performance of Chinese companies' foreign direct investment fluctuates or performs poorly, the underlying reasons are improper institutional arrangements, dislocation of investment entities and government behavior. In terms of influencing factors, different scholars test the its effect to foreign investment

b* Corresponding author: Li.ran@bjtu.edu.cn 
performance based on government intervention, investment motivation[5-8]. The impact of investment location, entry mode, expansion speed and other angles on the performance of foreign investment is tested. In terms of the institutional factors that affect investment performance, there are not many existing literature studies, and most of them are in macro level[9-11]. These studies generally show that the home country and host country's policy systems and corporate foreign investment performance are significant related. Among all systems, the legal system, as the most universal and compulsory form, is the most direct factor in determining the performance of economic development, especially the legal system of the host country. Compared with the legal system of the home country and the international investment norms, the legal system is directly related to the enterprise. The impact of investment activities is more direct. Unfortunately, there are very few studies in the existing literature that specifically focus on the impact of the host country's legal system on investment performance.

This article uses 82 foreign direct investment data of Chinese listed companies in 30 countries (regions) from 2010 to 2019 , and analyzes the laws of the host country based on the legal system related to the investment and operation of the host country and the enterprise and the different factors of each investment entity and project. The impact of the system on the performance of Chinese enterprises' outward direct investment is an empirical analysis of the compliance of Chinese enterprises' outward direct investment operations, with a view to providing enlightenment for the theoretical research and practice of Chinese enterprises' outward direct investment.

\section{Model setting and data source}

\subsection{Model Setting}

We construct the following model for testing. The specific settings are as follows:

$$
\begin{aligned}
P E R F_{i}=\alpha_{0} & +\alpha_{1} L A W_{i}+\alpha_{3} D E V_{t}+\alpha_{4} R E S_{i}+\alpha_{5} \ln T E C H_{i}+\alpha_{6} E N V_{i}+\alpha_{7} U N I_{i} \\
& +\alpha_{8} S H H_{i}+\alpha_{9} E X P_{i}+\alpha_{10} S P P_{i}+\alpha_{11} B I T_{i}+\varepsilon_{i}
\end{aligned}
$$

$$
\begin{aligned}
L A W_{i}=\beta_{0} & +\beta_{1} L A W_{i}+\beta_{2} R E S_{i}+\beta_{3} \ln T E C H_{i}+\beta_{4} E N V_{i}+\beta_{5} U N I_{i} \\
& +\beta_{6} S H H_{i}+\beta_{7} E X P_{i}+\beta_{8} S P P_{i}+\beta_{9} B I T_{i}+\varepsilon_{i}
\end{aligned}
$$

PERF ${ }_{i}$ represents the foreign direct investment performance of Chinese enterprise $i . L A W_{i}$ indicates the soundness of the legal system of the country where the target of Chinese enterprise $i$ M\&A is located, measured by the Rule of Law index in WGI released by the World Bank. $D E V_{i}$ represents the economic development level of the country where the target of Chinese company $i$ $\mathrm{M} \& \mathrm{~A}$ is located. This variable is a dummy variable. If the host country is a developed country, it is taken as 1 , and a developing country is taken as $0 . R E S_{i}$ indicates the resource endowment of the country where the target of Chinese enterprise $i \mathrm{M} \& \mathrm{~A}$ is located, measured by the ratio of the country's fuel and mineral exports to the total export value.lnTECH $i$ Indicates the technical level of the country where the target of Chinese enterprise $i$ M\&A is located, measured by the natural logarithm of the sum of patent applications by residents and non-residents of that country. $E N V_{i}$ indicates the ecological environment index of the country where the target of Chinese enterprise $i$ M\&A is located. $U N I_{i}$ indicates the density of the host country's trade union in the country where the target of Chinese enterprise $i$ M\&A is located, as measured by the number of trade union members in that country as a percentage of the total population per thousand. $\mathrm{SHH}_{i}$ indicates the nature of ownership of Chinese enterprise $i$. If it is a state-owned enterprise, it is taken as 1 , and otherwise it is taken as $0 . E X P_{i}$ represents the international investment experience of Chinese enterprise $i$, which is a dummy variable. If it has international investment experience, it is taken as 1 , otherwise it is taken as $0 . S P P_{i}$ indicates the proportion of Chinese enterprise i's acquisition of the target company's equity. $B I T_{i}$ indicates a bilateral investment agreement. If a bilateral investment agreement has been signed between China and the host country when a company invests directly in the host country, it will be taken as 1 , otherwise it will be taken as $0 . \varepsilon_{i}, \omega_{i}$ with $\varphi_{i}$ All are random disturbance items.

\subsection{Data Sources}

At present, from the perspective of the country as a whole, there are relevant data that distinguish cross-border mergers and acquisitions and greenfield investment to calculate China's foreign direct investment. From the perspective of enterprises, the statistical data of enterprises' foreign investment projects are mainly concentrated in the field of cross-border mergers and acquisitions. There are no statistics on investment projects for individual companies. The overseas subsidiaries after the completion of cross-border mergers and acquisitions of Chinese enterprises are very similar to the newly established overseas subsidiaries of Greenland Investment. They are also supervised by the host country's legal system, and the performance of the host country's legal system is similar. Therefore, based on the availability, completeness and accuracy of the relevant data, this article selects the actual "completed" projects in the overseas M\&A cases of Chinese companies from 2010 to 2019 as a sample, and through the investment companies a period of time after the completion of the acquisition project (3 years) Comprehensive evaluation of financial indicators, comparing the financial data of enterprises before the acquisition, and obtaining the evaluation of the performance of Chinese enterprises' foreign investment.

\subsection{Variable setting}

- Explained variable: the performance of the foreign investment company, which is represented by the comprehensive financial indicators of the three years after the completion of the acquisition of the 
investment company (including the year of the acquisition) compared with the financial indicators of the two years before the acquisition.

- Core explanatory variables: the quality of the host country's legal system. This indicator is expressed by the "Rule of Law" in the World Governance Indicators (WGI) released by the World Bank. The Rule of Law contains 6 items of data, among which the Estimate value is $-2.5 \sim 2.5$, which represents the rule of law index of each country.

- Control variables: The control variables involved in the empirical analysis in this section are slightly different from those in the previous section. Two variables that are not directly related to the performance of the company's foreign investment operations have been deleted, namely "openness of the host country (OPEN)" and "investment industry (IND)" Variables, the "Host Country Ecological Environment Index (ENV)", which is directly related to the performance of enterprises' foreign investment operations, has been added. Although other control variables are commonly used in the two sections of empirical analysis, the impact of each variable on the core explanatory variables is not the same. The other variables including the host country's economic development level (DEV), the host country's resource endowment (RES), the technological level of the host country (TECH), the host country's ecological environment index (ENV), the host country's union density (UNI), the nature of the ownership of the enterprise (SHH), Enterprise international investment experience (EXP), the shareholding ratio (SPP) and the bilateral investment agreement (BIT). The definition of these variables and data sources involved in the empirical research are shown in Table 1.

Table1. Definition and Description of the variable

\begin{tabular}{|c|c|c|c|}
\hline Type & Variables & Description & Data Source \\
\hline $\begin{array}{l}\text { Explained } \\
\text { variable }\end{array}$ & PERF & $\begin{array}{l}\text { Outward Direct } \\
\text { Investment } \\
\text { Performance of } \\
\text { Chinese } \\
\text { Enterprises }\end{array}$ & $\begin{array}{l}\text { Listed company } \\
\text { annual report }\end{array}$ \\
\hline $\begin{array}{l}\text { Core } \\
\text { explantory } \\
\text { variable }\end{array}$ & LAW & $\begin{array}{l}\text { The economic } \\
\text { development } \\
\text { level of the host } \\
\text { country }\end{array}$ & $\begin{array}{l}\text { "World Investment } \\
\text { Report" issued by } \\
\text { the World Bank }\end{array}$ \\
\hline \multirow{5}{*}{$\begin{array}{l}\text { Control } \\
\text { variables }\end{array}$} & DEV & $\begin{array}{l}\text { Host country } \\
\text { resource } \\
\text { endowment }\end{array}$ & $\begin{array}{l}\text { "World Investment } \\
\text { Report" issued by } \\
\text { the World Bank }\end{array}$ \\
\hline & RES & $\begin{array}{l}\text { Host country } \\
\text { resource } \\
\text { endowment }\end{array}$ & \multirow{2}{*}{$\begin{array}{lr}\text { United } & \text { Nations } \\
\text { UNCTAD database } \\
\text { and World } & \text { Trade } \\
\text { Organization } & \text { WTO } \\
\text { database } & \end{array}$} \\
\hline & TECH & $\begin{array}{l}\text { Host country } \\
\text { technical level }\end{array}$ & \\
\hline & \multirow[b]{2}{*}{ ENV } & \multirow[b]{2}{*}{$\begin{array}{l}\text { Host Country } \\
\text { Ecological } \\
\text { Environment } \\
\text { Index }\end{array}$} & $\begin{array}{l}\text { "Global } \\
\text { Environmental } \\
\text { Competitiveness }\end{array}$ \\
\hline & & & $\begin{array}{l}\text { Report (2015)" } \\
\text { issued by the } \\
\text { National } \\
\text { Comprehensive } \\
\text { Economic } \\
\text { Competitiveness } \\
\text { Research Center }\end{array}$ \\
\hline
\end{tabular}

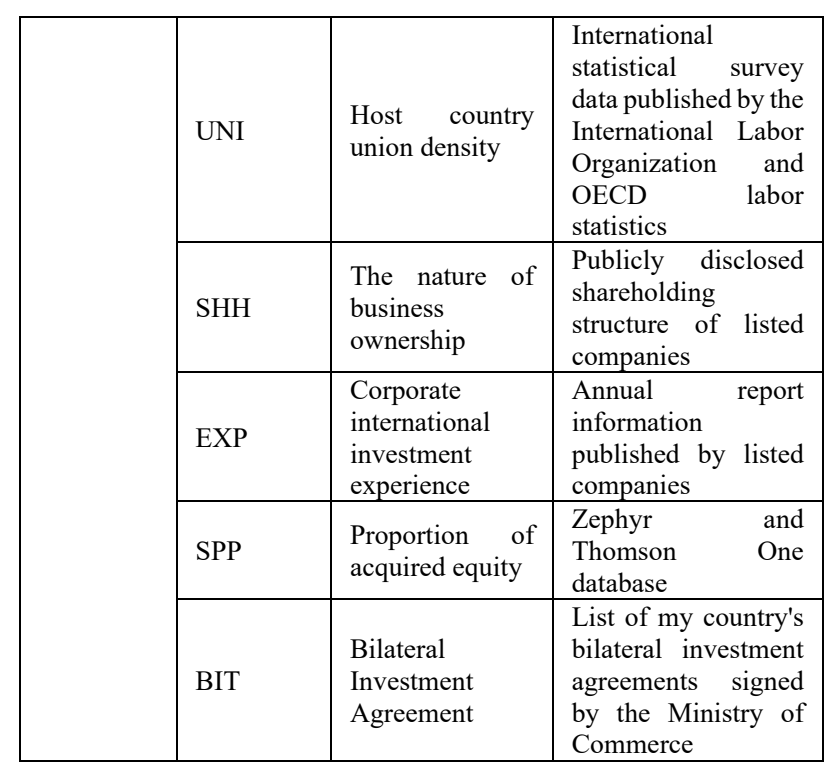

\section{Empirical results and analysis}

\subsection{The impact of the host country's legal system on the performance of investment enterprises}

This part tests the impact of the soundness of the host country's legal system on the performance of the investment company. The estimated results are shown in Table 2. The test result of column (1) shows that the estimated coefficient of the soundness of the host country's legal system is positive, but it fails in the statistical significance test. The estimated result of column (2) is the estimated result including the control variable. The estimated result shows that the host country's coefficient of the soundness of the legal system is positive, and it can pass the statistical significance test at a significance level of 5\%, indicating that with other factors unchanged, with the improvement of the soundness of the legal system of the host country, the performance of the investment enterprise will gradually improve.

\subsection{The impact of the economic development level of the host country on the quality of the legal system}

This part tests the impact of the host country's economic development level on the soundness of the host country's legal system. The estimated results are shown in Table 2. The test result of column (3) shows that the estimated coefficient of the economic development level of the host country is positive, but it can pass the statistical significance test at a significance level of $1 \%$, indicating that the economic development level of the host country has a significant positive correlation with the soundness of the legal system. The estimation result in column (4) is the estimation result including the control variables. The result shows that the estimated coefficient of the soundness of the host country's legal system is positive, and it can pass the statistical significance test at the $1 \%$ significance level, indicating that if other factors unchanged, with the improvement of the host country's 
economic development level, the soundness of the host country's legal system will continue to increase.

\subsection{Heterogeneity test based on the nature of enterprise property rights}

This part starts from the nature of enterprise property rights to test whether the impact of the host country's economic development level on the soundness of the host country's legal system is significantly different between state-owned enterprises and private enterprises. The test result of column (5) shows that the estimated coefficient of the interaction term between the soundness of the host country's legal system and the property of property variables is negative, and it can pass the statistical significance test at a significance level of $1 \%$, indicating that this effect is significantly different between stated owned enterprises and private enterprises. The estimation result in column (6) shows that the estimated coefficient of the interaction term between the soundness of the host country's legal system and the property variable is negative, and it can pass the statistics at the $1 \%$ significance level. While keeping other factors unchanged, the host country's legal system has a greater inhibitory effect on the performance of investment enterprises in the sample of state-owned enterprises.

\subsection{Heterogeneity test of the investment industry}

This part starts from whether the investment industry field is a sensitive field, and tests whether the impact of the host country's economic development level on the soundness of the host country's legal system is significantly different between sensitive and non-sensitive fields. The estimated results are shown in Table 2. The test result of column (7) shows that the estimated coefficient of the interaction term between the soundness of the host country's legal system and the investment industry is negative, and it can pass the statistical significance test at a significance level of $1 \%$, indicating that this effect is significantly different between sensitive and non-sensitive areas. The estimation result in column (8) is the estimation result including the control variables. The estimation result shows that the interaction term between the soundness of the host country's legal system and the investment industry field is negative. Significance test shows that while keeping other factors unchanged, the host country's legal system has a greater restraint on the performance of investment companies in sensitive areas.

Table2. Regression Results

\begin{tabular}{|c|c|c|c|c|c|c|c|c|}
\hline \multirow[t]{2}{*}{ Variable } & (1) & (2) & (3) & (4) & (5) & (6) & (7) & (8) \\
\hline & PERF & PERF & LAW & LAW & PERF & PERF & PERF & PERF \\
\hline \multirow[t]{2}{*}{ LAW } & 0.76 & $4.53^{* *}$ & & & -0.27 & 2.62 & -0.23 & 2.94 \\
\hline & $(0.69)$ & $(2.24)$ & & & $(-0.19)$ & $(1.19)$ & $(-0.16)$ & $(1.34)$ \\
\hline \multirow{2}{*}{$\begin{array}{l}\text { LAW_- } \\
\text { SHH }\end{array}$} & & & & & $-0.61^{* * *}$ & $-0.58^{* * *}$ & & \\
\hline & & & & & $(-37.77)$ & $(-4.20)$ & & \\
\hline \multirow{2}{*}{$\begin{array}{l}\text { LAW_- } \\
\text { IND }\end{array}$} & & & & & & & $-0.60^{* * *}$ & $-0.58^{* * *}$ \\
\hline & & & & & & & $(-25.70)$ & $(-5.41)$ \\
\hline \multirow[t]{2}{*}{$\overline{\mathrm{DEV}}$} & & 5.72 & $1.55^{* * *}$ & $1.42^{* * *}$ & & $8.36^{*}$ & & $7.90^{*}$ \\
\hline & & $(1.28)$ & $(10.21)$ & $(4.83)$ & & $(1.79)$ & & $(1.70)$ \\
\hline \multirow[t]{2}{*}{ RES } & & $1.32^{* *}$ & & 0.01 & & $1.33^{* *}$ & & $1.30^{* *}$ \\
\hline & & $(2.58)$ & & $(0.52)$ & & $(2.39)$ & & $(2.34)$ \\
\hline \multirow[t]{2}{*}{$\ln \mathrm{TECH}$} & & $-2.51^{* *}$ & & 0.02 & & $-2.34^{*}$ & & $-2.42^{* *}$ \\
\hline & & $(-2.29)$ & & $(0.42)$ & & $(-1.93)$ & & $(-2.00)$ \\
\hline \multirow[t]{2}{*}{ ENV } & & $-0.62^{*}$ & & $0.04^{*}$ & & -0.55 & & -0.53 \\
\hline & & $(-1.72)$ & & $(1.72)$ & & $(-1.44)$ & & $(-1.41)$ \\
\hline \multirow[t]{2}{*}{ UNI } & & $5.42^{*}$ & & -0.00 & & 5.48 & & 5.28 \\
\hline & & $(1.74)$ & & $(-0.00)$ & & $(1.65)$ & & $(1.56)$ \\
\hline \multirow[t]{2}{*}{ SHH } & & -0.18 & & -0.09 & -2.63 & 0.33 & & 0.93 \\
\hline & & $(-0.07)$ & & $(-0.91)$ & $(-0.68)$ & $(0.17)$ & & $(0.49)$ \\
\hline \multirow[t]{2}{*}{ EXP } & & $12.57^{* * *}$ & & -0.05 & & $12.41^{* * *}$ & & $12.76^{* * *}$ \\
\hline & & $(3.78)$ & & $(-0.34)$ & & $(3.25)$ & & $(3.30)$ \\
\hline \multirow[t]{2}{*}{ SPP } & & 1.84 & & 0.21 & & 2.86 & & 2.97 \\
\hline & & $(0.82)$ & & $(1.36)$ & & $(1.34)$ & & $(1.39)$ \\
\hline \multirow[t]{2}{*}{ BIT } & & $-11.51^{* *}$ & & 0.02 & & $-12.31^{* *}$ & & $-11.91^{* *}$ \\
\hline & & $(-2.22)$ & & $(0.07)$ & & $(2.33)$ & & $(-2.25)$ \\
\hline \multirow[t]{2}{*}{ IND } & & & & & & -0.44 & -2.74 & -1.15 \\
\hline & & & & & & $(-0.18)$ & $(-0.91)$ & $(-0.48)$ \\
\hline \multirow[t]{2}{*}{ Constant } & -0.03 & $44.92^{*}$ & -0.02 & $-2.18^{*}$ & 2.88 & 39.10 & 2.76 & 38.76 \\
\hline & $(-0.18)$ & $(1.92)$ & $(-0.13)$ & $(-1.79)$ & $(0.58)$ & $(1.57)$ & $(0.68)$ & $(1.55)$ \\
\hline $\mathrm{N}$ & 82 & 79 & 82 & 79 & 82 & 79 & 82 & 79 \\
\hline Adjusted R2 & -0.01 & 0.27 & 0.67 & 0.67 & 0.02 & 0.27 & 0.03 & 0.27 \\
\hline $\mathrm{F}$ & 0.48 & 3.89 & 104.22 & 18.70 & 494.23 & & 627.19 & \\
\hline
\end{tabular}

\section{Conclusions and recommendations}

\subsection{Conclusion}

From the perspective of the "operational compliance" of Chinese enterprises' foreign direct investment, this paper conducts an empirical analysis of the influence of the host country's legal system on the success or failure of Chinese enterprises' foreign direct investment, and draws the following conclusions: 
In the actual operating stage of foreign direct investment projects, with the improvement of the soundness of the host country's legal system, the performance of Chinese companies investing in the country will gradually improve, and the host country's resource endowment, technological level, ecological environment level, trade union density, and corporate international investment experience is also opposite to the performance level of investment enterprises. In short, with the increase of host country's resource endowment, technological level, ecological environment level, host country's union density and the increase of enterprises' international investment experience, the performance of investment enterprises will gradually improve. There is a significant positive correlation between the economic development level of the host country and the soundness of the legal system. With the improvement of the economic development level of the host country, the soundness of the legal system of the host country will continue to improve. Further heterogeneity analysis shows that in the actual operation stage of foreign direct investment projects, there are significant differences in the correlation between the soundness of the host country's legal system and the performance of the investment company. There also exists some differences between state-owned enterprises and private enterprises. The results between sensitive and non-sensitive areas are also different.

\subsection{Suggestions}

This article also has a good reference for policy makers and business operators:

In terms of policy formulation, in order to support and protect my country's enterprises' foreign direct investment and ensure that enterprises' foreign investment achieves the expected performance, it is necessary for the government to improve a series of foreign investment promotion and guarantee systems. At present, our country does not have a formal, complete and systematic law to regulate. The current foreign investment legislation presents the characteristics of "regarding supervision and neglecting protection", and mainly focuses on the regulatory approval of overseas investment projects, foreign exchange control, and state-owned assets supervision. The relevant laws and regulations on foreign investment protection are scattered in departmental regulations and lack systematization. The level of law is not high, seriously lagging behind the practice of my country's foreign direct investment. Thus, the government should formulate the Foreign Investment Law as the basic legal system for foreign investment as soon as possible, which could command China's foreign investment legal system. Based on this law, we could formulate and improve a series of legal systems related to the promotion, management, and protection of domestic enterprises' foreign investment, especially an outbound investment protection and promotion system.

In terms of business operations, as the most important subject of foreign direct investment activities, foreign investment enterprises dominate the entire process of foreign investment and directly determine whether the performance of foreign investment can be achieved. In order to reduce the adverse impact of the host country's legal system on foreign investment, Chinese companies can learn from the experience of multinational investment companies, make full use of the foreign investment protection system provided by the home country government, and adopt a series of measures to effectively prevent and control the legal risks of foreign investment, which could maximize the improvement of enterprises' performance of foreign investment. First of all, enterprises cannot blindly follow the trend in foreign investment, and they cannot rush to implement it without preparation. Before implementing foreign investment, enterprises should formulate a global development strategy based on their own development positioning and needs, combined with the respective advantages of resources around the world. Secondly, before implementing foreign investment, companies should conduct a comprehensive and in-depth investigation on the legal system of the host country and the legal affairs of the target company, avoid transaction risks caused by information asymmetry as much as possible. Then, it could provide an important basis for foreign investment decisions and transaction documents. Enterprises should also formulate comprehensive, systematic and feasible acquisition plans and integration plans based on their own existing conditions, development strategies and goals, combined with the resource advantages, development direction and needs of the target company, so as to achieve complementary advantages, coordinated development, and mutual benefit. In addition, companies should also strengthen the spirit of contract and investment insurance awareness, make good use of contracts to allocate transaction risks reasonably, and actively use China Credit Insurance and MIGA's guarantee mechanism to protect the rights and interests of foreign investment. Finally, companies need to strengthen overseas subsidiaries Compliance management. The landing of foreign investment projects or the delivery of property rights is only the first step in the long march. The operating stage after the investment project has landed is the key link that determines the investment performance. Chinese enterprises need to study the relevant legal systems of the host country in depth, formulate and effectively implement overseas business compliance systems based on this, to ensure compliance operations and guarantee investment performance.

\section{References}

1. Ban B, Ren H G. (2008) A Study of the Performance Evaluation System of Foreign Direct Investment of Chinese Enterprise. Journal of Shandong University (Phiosophy and Social Sciences), (2): 104-109.

2. Chang Y C. (2011) Dynamic Characteristics of Overseas Direct Investment of Chinese Enterprises: An Empirical Analysis Based on Large State-owned Enterprises. Finance \& Trade Economics, (2): 87-94.

3. Du W J, Bai W S, Liu H. (2010) An Empirical Study on the Performance of Chinese Enterprises' Outward Direct Investment: Taking Chinese Listed 
Companies' Overseas Investment as an Example. Communication of Finance and Accounting, (6): 7376.

4. Li J, Ran G H, Wang J. (2008) Analysis on the Causes of the Poor Performance of Chinese Enterprises' Foreign Direct Investment. Productivity Research, (3): 69-71.

5. Jiang G S, Li W A. (2016) How Does Government Intervention Affect OFDI? An Institutional Theory Perspective. Journal of Finance and Economics, (3): 122-133.

6. Li J Y, Xia C W. (2005) Research on the Motivation and Performance of Foreign Capital M\&A of my country's Listed Companies. Research on Financial and Economic Issues, (6): 69-72.

7. Bai T, Jiao J, Jin Z M, Wang W L. (2013) Location, Entry Mode Choice and Survial of Chinese Firms' Outward FDI. Journal of Tsinghua University (Science and Technology), (2): 280-288.

8. Zhou Y, Zheng Y H. (2019) Rapid OFDI Expansion and Firm Performance_—_Evidence from China. Journal of International Trade, (1): 132-146.

9. Wang Z Y, Liu G, Liang H. (2019) Research on Diversity Choice of China's Companies Making Outward Foreign Direct Investment and It's Performance. China Industrial Economics, (3): 5-23.

10. Zhang W R, Han B, Hu B. (2012) China Outward Foreign Direct Investment Performance and Economic Growth: Empirical Analysis Based on Provincial Panel Data. On Economic Problems, (11):54-56

11. Chen J X, Luo Y. (2015) The Assessment, Comparision and Implications of Outward FDI Performance in BRIC Countries. Asia-pacific Economic Review, (3): 92-97. 